\title{
HOW EFFECTIVE ARE LABOR WAGES ON LABOR PRODUCTIVITY?: AN EMPIRICAL INVESTIGATION ON THE CONSTRUCTION INDUSTRY OF NEW ZEALAND
}

\author{
Mustafa OZTURK ${ }^{1}$, Serdar DURDYEV (D)2* ${ }^{*}$, Osman Nuri ARAS ${ }^{3}$, \\ Syuhaida ISMAIL ${ }^{2}$, Nerija BANAITIENE ${ }^{4}$ \\ ${ }^{1}$ Independent researcher, Istanbul, Turkey \\ ${ }^{2}$ Razak Faculty of Technology and Informatics, Universiti Teknologi Malaysia, \\ Jalan Sultan Yahya Petra, 54100 Kuala Lumpur, Malaysia \\ ${ }^{3}$ Faculty of Arts and Social Sciences, Nile University of Nigeria, Abuja FCT, 900001 Nigeria \\ ${ }^{4}$ Department of Construction Management and Real Estate, Vilnius Gediminas Technical University, \\ Sauletekio al. 11, 10223 Vilnius, Lithuania
}

Received 15 July 2019; accepted 30 October 2019

\begin{abstract}
This study empirically investigates (for the period of 1983-2017) the relationships between the parameters (labour wage (LW), labour productivity (LP) and unemployment (UNM) rate) of the construction sector in New Zealand. This study employs the Johansen co-integration test to determine if the relationship in the long run does exist among the investigated variables as well as to assess the relationships. The results show that the LW has a positive effect on the LP, while the UNM affects negatively, which indicates that the higher salary, the more productive labour. In other words, increase in salary stimulates the belief of the workforce that they are substantially paid for their work, which ultimately increases their trust and loyalty to the employer; hence, productivity. Moreover, the results show adverse effect of UNM on LP, which indicates that labours may also lose his/her productivity due to fear of losing his/her job. The model stability is verified by Histogram Normality Test, Breusch-Godfrey Serial Correlation, Heteroscedasticity Breusch-Pagan-Godfrey tests. Thus, the forefront of the construction sector is recommended to consider the empirical relationships determined in this study in order to improve the productivity level at various levels.
\end{abstract}

Keywords: productivity, construction industry, labour wage, unemployment, New Zealand.

JEL Classification: E10, E24, J24.

\section{Introduction}

Theoretical evidence suggests that a competitive market necessitates the labour productivity (LP) to be a determinant of labour wage (LW). The relationship between the two variables have been anchored by economic theory, as such, the higher LP should - theoretically - re-

${ }^{\star}$ Corresponding author. E-mail: sdurdyev@gmail.com

This is an Open Access article distributed under the terms of the Creative Commons Attribution License (http://creativecommons. org/licenses/by/4.0/), which permits unrestricted use, distribution, and reproduction in any medium, provided the original author and source are credited. 
sult in wage increase (Akerlof, 1982). The Keynesian and Classical approaches also reveal that LW is considered to be a determinant of LP. However, some studies proposed an opposite direction in causality between LW and LP (Policardo et al., 2019). Moreover, several factors, such as economic and institutional, may affect the theoretical nexus between LW and LP, and therefore, inconsistency between the theory and reality. As such, recent global trend reveals that the increase in wages has not been as rapid as LP, which consequently leads to a decrease in share of income paid to compensate the labour (Van Biesebroeck, 2007). Therefore, the relationship between LP and LW is considered to be complicated, which has been investigated by several economic theories.

Review of the available literature on the subject shows various studies from various regions, countries and sectors have investigated causal relationship between the wage and productivity (Rizov et al., 2016; Ehrenberg \& Smith, 2009; Falk et al., 2005; Forth \& O’Mahony, 2003). Various wage levels or terminologies have been used while investigating the relationship, such as "minimum wage" (Rizov et al., 2016), "real wage" (Yildirim, 2015), "wage inequality" (Policardo et al., 2019) and "wage solidarity" (Meidner \& Rehn, 1952). For example, using the data from thirty-four OECD countries, Policardo et al. (2019) investigate the relationship between wage inequality and LP. Their investigation reveals the existence of association in between larger inequality in wage and low LP. Another study reports the strong nexus between LW and LP (Ehrenberg \& Smith, 2009), which reveals that the higher wage the higher productivity of the current employees. As it can be seen much of the current body of knowledge investigating the relationship between the wage and productivity is either country-, sector- or region-specific. Thus, any research that investigates the relationship between these sectoral parameters may not represent, and/or applicable to the construction industry context of New Zealand; therefore, a particular investigation is required. Moreover, according to the efficiency wage theory (EWT), the causal relationship runs from wages to productivity (Wakeford, 2004). Thus, this theory, hypothetically, suggests that increase/decrease in wages results in increase/decrease in productivity. With these in mind, this paper attempts to answer the question: Can LW stimulate the productivity performance of a labour? To answer this question, various statistical techniques (refer to the Variables and Methodology section) were used to investigate the relationship between LW and LP in the construction industry of New Zealand. The unique contribution of the study is to investigate the relationship between the above-mentioned parameters within the construction context of New Zealand and assess if the relationship is consistent with the EWT.

After providing the introductory statements and the aim the research, the paper continues with the presentation of an in-depth review (Section 1) of the context on the subject. Section 2 and Section 3 present the data utilized and the results of the data analysis, respectively. The rest of the paper presents the results and discussion on the long-term relationships between the variables considered. The last section presents the concluding remarks on the significant findings of the research as well as its implications.

\section{Review of the literature}

Several studies in the literature have reported strong association of economic growth with productivity (Ozturk et al., 2019). Park et al. (2005) point out the importance of improvement 
in the industry productivity which will bring an economic success for companies aiming to survive in the competitive industry environment. Productivity, based on the level, enables to achieve set goals, conserve strategic and financial health, as well as create a competitive atmosphere in the industry or entire economy (Nazarko \& Chodakowska, 2017; Banaitiene et al., 2015; Durdyev \& Mbachu, 2011). There are different levels, where productivity plays role in terms of achieving set objectives and making a contribution to overall growth (Shoar \& Banaitis, 2019; Durdyev \& Mbachu, 2018). For instance, productivity triggers growth and development of the national economy, and indicates potential for improved material standards and increases in the society's general welfare as well as more leisure time for the inhabitants. On the other hand, productivity is one of the most significant components for the success of any company, which translates directly into profitability (Durdyev \& Ismail, 2016).

Productivity has been widely defined as the sector's ability to generate output by utilizing inputs, such as money, men, material and machinery (Oyeranti, 2000; Durdyev, 2011) or a quantification of the ratio between inputs and outputs (Han et al., 2017). In other words, how effectively resources are utilized to achieve project objectives (Durdyev et al., 2018; Ma et al., 2017).

It has been reported that changes in wages may cause changes in productivity (Yildirim, 2015). Positive relationship between these two parameters is referred to two arguments that are reported in the literature. The first one dictates that higher wages result in costly job losses for labours (Storm \& Naastepad, 2012). In other words, the higher-paid labours will show greater effort to maintain their employment; hence, labour productivity will be improved. The second one explains the relationship between two parameters from a macroeconomic perspective. It suggests that any increase in wages will result in substitution of capital with labour and ultimately increase marginal productivity (Wakeford, 2004).

The mainstream economic literature comprises various studies investigated the relationship among the economic parameters, such as labour wage (LW), labour productivity (LP) and unemployment (UNM). Thus, this topic evidently has attracted broad attention from the researchers in the area. For example, in the study where various estimation techniques were used, Rezai and Semmler (2007) empirically analysed the impact of LP on the UNM and found that in the short run the impact of LP on UNM is positive, while in the long run the growth in LP results in reduction of UNM. In another study investigation on the relationship between LP and LW growth (between 1980 and 2005) in the OECD countries and Canada is reported (Sharpe et al., 2008). The study concludes that during the investigated period the RWs of Canadian labours stagnated even though there was an increase in LP by $37 \%$. This study further investigated the reasons behind this result and identified three factors that had equal contribution, which are measurement issues, increase in income inequality and decrease in workforce's share in GDP. A positive relationship (at the national level) between the growth of both LP and LWs has also been reported by Meager and Speckesser (2011), where they utilized the data for 25 European countries between 1995 and 2009.

In another study, for the period of 2007-2016, Karaalp-Orhan (2017) employs Toda-Yamamoto test of causality and utilizes the bounds testing approach within the auto-regressive distributed lag modelling to analyse the nexus between LP, average LW, and UNM rate. The study suggests that there is a positive and significant impact of both LWs and UNM on LP 
in the long run. In addition, the causality test results are a clear evidence of the impact of UNP rate on both LP and LWs. It is worthwhile mentioning that the study also reported a mutual causality between LP and UNP and unilateral causality between UNM and LWs. Further, Yildirim (2015) employs Granger causality test (GCT) and co-integration analysis to examine the interrelationships among LP, LW and inflation rate in the manufacturing industry of Turkey during 1988-2012. The results reveal that inflation rate has greater impact on LP than LWs, while the GCT indicates that no causal link exists running from LP to LWs in the manufacturing industry. In the recent study by Katovich and Maia (2018) report the relationship between the dynamics of LP and LW in Brazil between 1996-2014. In the study the hierarchical data models are estimated to evaluate the effects of national- and sectorlevel factors on labours' wages. The results revealed that LP and LW has positive and strong relationship in all sectors.

From the theoretical perspective, according to both the Classical and Keynesian approaches, LW is one of the significant determinants of LP. Although the classical view emphasizes on wage cut policy implementation to improve LP, Keynes focuses on the existing inverse relationship between real (RW) and money (MW) wages, which is explained as RW rises in case of reduction in MW. This is due to the fact that decrease in MW will result in more than proportionate decrease in prices. Consequently, RW increase due to the increase in value of money. Thus, the effect of LW on LP and their relationship have widely been reported worldwide. In the most recent study, which is one of the points of departure for the present study, Ozturk et al. (2019) reported an empirical assessment of the relationship between RW and LP in the construction sector based on data between 1983 and 2017. They concluded that the LP positively impacts the LW, while the UNP shows negatives effect in the long run. However, there is a need for further investigation on how LW is effective on LP. Thus, this study empirically tests the effect of LW on LP in the construction context in New Zealand between 1983-2017.

\section{Variables and the methodology}

Variables of the model are weekly LW, LP (Income) Index and UNM rate in the construction sector of New Zealand (refer to Table 1). The series were obtained as annual time series which are limited with the period between 1985 and 2017 because of the availability from Stats NZ Tatauranga Aotearoa.

Logarithmic values of the variables were used in the model and following the recommendations of Dickey and Fuller (1981), Augmented Dickey-Fuller Test (ADF) test was used to assess their stationarity. Afterwards, the Johansen co-integration (JC) test was employed

Table 1. Utilized variables

\begin{tabular}{|l|l|l|}
\hline \multicolumn{1}{|c|}{ Variables } & \multicolumn{1}{c|}{ Code of Variable } & \multicolumn{1}{c|}{ Type } \\
\hline LP (Income) Index & LnLAPROD & Endogenous \\
\hline UNM & LnUNIMP & Endogenous \\
\hline LW (Weekly) & LnWAGE & Endogenous \\
\hline
\end{tabular}


for further identification of the existence of any relationship between the variables in the long run. Further, the Vector Error Correction Mechanism (VECM) was used to find out the adjustment coefficient which shows the adjustment rate of the disequilibrium into the equilibrium. Moreover, Wald Test (WT) was applied to check if any relationship between the variables in the short run does exist. Lastly, residual diagnostic tests were performed to identify stability and reliability of the model.

\section{Unit Root Test (URT)}

Stationary time series follow stochastic proceedings and their autocorrelation structure, variance and means do not change over time. The results may be spurious and biased in case of the regression of non-stationary time series. Eliminating the trend and the seasonal effects from the series, differentiating of it and getting its logarithmic values are the approaches to make the non-stationary series stationary. The variables that were included in the model for the co-integrating tests were all at their level $\mathrm{I}(0)$ in case they are all stationary at the same level. Therefore, the stationarity of the variables was assessed with ADF test which is formulized as follow:

$$
\begin{gathered}
\Delta X_{t}=a+b t+\alpha X_{t-1}+\beta \sum_{i=1}^{m} \Delta X_{t-i}+e_{t} ; \\
\Delta X_{t}=a+\alpha X_{t-1}+\beta \sum_{i=1}^{m} \Delta X_{t-i}+e_{t} .
\end{gathered}
$$

Eq. (1) and (2) show the stationarity with and without a trend, respectively. Null hypotheses are $\mathrm{H} 0: \alpha=0$ and $\mathrm{H} 0: \mathrm{b}=0$ that means $X_{t}$ series is not stationary; however alternative hypothesis is $\mathrm{H} 1: \alpha \neq 0$ and $\mathrm{b} \neq 0$ that means $X_{t}$ series is stationary. Alternative hypothesis is accepted if the $\mathrm{HO}$ is rejected. ADF URT results show that the series are not stationary at their base level I(0), while their I(1) (first differences) are stationary (refer to Table 2).

Table 2. Variables' stationarity

\begin{tabular}{|l|c|c|c|c|c|c|c|c|c|c|}
\hline Variables & \multicolumn{4}{|c|}{ Without trend } & \multicolumn{5}{c|}{ With trend } \\
\hline & $\tau$ & $\% 1$ & $\% 5$ & $\% 10$ & Prob & $\tau$ & $\% 1$ & $\% 5$ & $\% 10$ & Prob \\
\hline LnLAPROD & -2.90 & -2.64 & -1.95 & -1.61 & 0.01 & -3.71 & -4.30 & -3.57 & -3.22 & 0.04 \\
\hline LnUNIMP & -3.28 & -2.64 & -1.95 & -1.61 & 0.00 & -3.30 & -4.28 & -3.56 & -3.22 & 0.09 \\
\hline LnWAGE & -4.69 & -2.64 & -1.95 & -1.61 & 0.00 & -5.22 & -4.28 & -3.56 & -3.22 & 0.00 \\
\hline
\end{tabular}

Notes: Number 1 in codes of variable shows that the first level difference of that serie is taken. ${ }^{*}$ symbolizes level of the serie as $\% 1$ and ${ }^{* *}$ as $\% 5$.

\section{Granger causality test (GCT)}

The GCT was used to determine the causality among the variables and its direction, as presented in Table 3. Thus, the following equations ((3) and (4)) can be used for the causality between $\mathrm{x}$ and y variables (Granger, 1969):

$$
y_{t}=a_{0}+\sum_{i=1}^{n} \beta_{i} x_{t-i}+\sum_{i=1}^{n} a_{i} y_{t-i}+u_{i} ;
$$




$$
x_{t}=\beta_{0}+\sum_{i=1}^{n} a_{i} y_{t-i}+\sum_{i=1}^{n} \beta_{i} x_{t-i}+u_{i},
$$

where: $\alpha_{0}$ and $\beta_{0}=$ intercepts; $\alpha_{i}$ and $\beta_{i}=$ coefficients of the variables; $\mu=$ the error term of the equations.

Causality tests made with non-stationary series may be spurious so the series eliminated from the unit root through differentiating.

Table 3. Pairwise GCT

\begin{tabular}{|l|c|c|c|}
\hline \multicolumn{1}{|c|}{ H0 } & Obs & F-Stat. & Prob. \\
\hline$\Delta$ LnUNIMP does not Granger Cause (GC) $\Delta$ LnLAPROD & 31 & 11.0272 & 0.0003 \\
\hline$\Delta$ LnLAPROD does not GC $\Delta$ LnUNIMP & & 3.54681 & 0.0434 \\
\hline$\Delta$ LnWAGE does not GC $\Delta$ LnLAPROD & 31 & 6.22978 & 0.0062 \\
\hline$\Delta$ LnLAPROD does not GC $\Delta$ LnWAGE & & 0.56489 & 0.5752 \\
\hline$\Delta$ LnWAGE does not GC $\Delta$ LnUNIMP & 32 & 9.10809 & 0.0009 \\
\hline$\Delta$ LnUNIMP does not GC $\Delta$ LnWAGE & & 0.90702 & 0.4157 \\
\hline
\end{tabular}

Test results display that the UNM rate has a causality on the LP at the $0.03 \%$ significance level as well as the LW has it at $0.6 \%$ significance level.

\section{VAR lag order selection}

The optimum lag order of the variables for co-integration test is determined with VAR model based on the following criteria (refer to Table 4); Schwarz information (SC), Hannan-Quinn (HQ), Akaike (A), Final prediction error (FPE) and Likelihood Ratio (LR). The optimum lag order is 1 by the consensus of all the criteria.

Table 4. Selection of the VAR lag order

\begin{tabular}{|c|c|c|c|c|c|c|}
\hline Lag & LogL & LR & FPE & A & SC & HQ \\
\hline 0 & 31.53737 & NA & $2.80 \mathrm{e}-05$ & -1.968095 & -1.826650 & -1.923796 \\
\hline 1 & 172.4709 & $242.9889^{\star}$ & $3.15 \mathrm{e}-09^{\star}$ & $-11.06696^{\star}$ & $-10.50118^{\star}$ & $-10.88977^{\star}$ \\
\hline 2 & 179.7871 & 11.10039 & $3.63 \mathrm{e}-09$ & -10.95083 & -9.960724 & -10.64074 \\
\hline 3 & 187.8909 & 10.61876 & $4.09 \mathrm{e}-09$ & -10.88903 & -9.474583 & -10.44604 \\
\hline 4 & 199.3894 & 12.68798 & $3.87 \mathrm{e}-09$ & -11.06134 & -9.222559 & -10.48545 \\
\hline 5 & 207.0207 & 6.841881 & $5.25 \mathrm{e}-09$ & -10.96695 & -8.703835 & -10.25817 \\
\hline
\end{tabular}

Note: ${ }^{\star}$ indicates lag order selected by the criterion. 


\section{Long term association between the labor wages and the productivity variables}

\subsection{Co-integration test}

Analyzes made by using the non-stationary time series with classical methods like ordinary least squares, may have biased or misleading results. These series have to be analyzed with different methods. Co-integration is a method with which non stationary time series can be analyzed. It estimates the long run relations between the non-stationary time series that have variances and means vary over time (Rao, 2007).

The JC Model is better option for the analysis since it allows to determine more than one co-integration relations between the variables. It is formulated as follow;

$$
x_{t}=[\mu+\Pi] x_{t-1}+\ldots \ldots \ldots . .+\Pi_{k} x_{t-k}+\varepsilon_{t} .
$$

$\varepsilon_{\mathrm{t}}$ is error term and $\mu, \Pi_{1} \ldots \Pi_{\mathrm{k}}$ are restricted parameters estimated by Vector Auto Regressive Model.

$$
\Delta x_{t}=\mu+\Gamma_{1[\Delta x]_{t-1}}+\ldots+\Gamma_{k-1}[x]_{t-k+1}+[\Pi x]_{t-1} \varepsilon_{t} .
$$

Since the series are not stationary, we made them stationary by having the first difference of each. The Eq. (3) converted into the Eq. (4) with this operation.

$$
\Gamma_{i}=-\left(\mathrm{I}-\Pi_{1}-\ldots \Pi_{i}\right) \quad i=1, \ldots k-1 \text { ve } \Pi=-\left(\mathrm{I}-\Pi_{1}-\ldots \ldots \ldots \Pi_{k}\right) .
$$

Coefficient matrix (CM) $\Pi$ was checked if there is a relation between the variables and the data vector. It may have one in three possible values;

If $\operatorname{Rank}(\Pi)=0$. Then $\mathrm{CM}(\Pi)=0$ and the Equation (6) is convenient with the traditional time series differential vector.

If $\operatorname{Rank}(\Pi)=\mathrm{p}$. Then $\mathrm{CM}(\Pi)$ is a whole rank and $\mathrm{X}$ vector process is stationary.

If $0<\operatorname{Rank}(\Pi)=\mathrm{r}<\mathrm{p}$. Then $\alpha \beta$ and $\mathrm{p}^{\star} \mathrm{r}$ are multiplied to obtain $\mathrm{CM}(\Pi)$, which means the variables are associated in the long run.

Since all variables are in the same order, JC test was performed. There is at least a unilateral causality among the variables in case of the integration of the variables (Granger, 1969). So the casualty between the variables was checked via standard GCT. Then, VECM model was performed to estimate the adjustment coefficient of the variables (Granger, 1988). The Trace and Maximum eigenvalue tests estimated the number of co-integrating vectors between the variables.

Table 5 shows that the TS value is higher than the CV at $0.04 \%$ significance level. Thus, the $\mathrm{H} 0$ that the variables are not co-integrated is rejected. But in the second line the TS value is less than the $\mathrm{CV}$, so the $\mathrm{H} 0$, which is at most one co-integration equation exists, is accepted.

As it is seen in Table 6, MES results confirm the TS that there is at least one co-integration equation indicating the long run relationship between the variables. The MES value is bigger than the $\mathrm{CV}$ at $0.24 \%$ significance level. Thus, the $\mathrm{H} 0$, which is the variables are not co-integrated, is rejected. But the MES value in the second line is less than the CV. Thus, the $\mathrm{H} 0$, which is at most one co-integration equation between the variables, is not rejected. 
Table 5. Trace test

\begin{tabular}{|c|c|c|c|c|}
\hline Hypothesized No. of CE(s) & Eigenvalue & Trace Stat. (TS) & 0.05 Critical Value (CV) & Prob. $^{* *}$ \\
\hline None $^{\star}(\mathrm{R}=0)$ & 0.688010 & 60.40131 & 42.91525 & 0.0004 \\
\hline At most $1(\mathrm{r} \leq 1)$ & 0.430144 & 25.45774 & 25.87211 & 0.0562 \\
\hline At most $2(\mathrm{r} \leq 2)$ & 0.248903 & 8.586610 & 12.51798 & 0.2074 \\
\hline
\end{tabular}

Notes: ${ }^{\star}$ The hypothesis is rejected at 5\% level; ${ }^{\star *}$ p-values (MacKinnon et al., 1999).

Table 6. Max. Eigen

\begin{tabular}{|l|c|c|c|c|}
\hline Hypothesized No. of CE(s) & Eigenvalue & Max-Eigen Stat. (MES) & 0.05 CV & Prob. $^{* *}$ \\
\hline None $^{*}(\mathrm{R}=0)$ & 0.688010 & 34.94356 & 25.82321 & 0.0024 \\
\hline At most $1(\mathrm{r} \leq 1)$ & 0.430144 & 16.87114 & 19.38704 & 0.1118 \\
\hline At most $2(\mathrm{r} \leq 2)$ & 0.248903 & 8.586610 & 12.51798 & 0.2074 \\
\hline
\end{tabular}

Notes: ${ }^{\star}$ The hypothesis is rejected at 5\% level; ${ }^{\star *}$ p-values (MacKinnon et al., 1999).

Table 7. Normalized vector

\begin{tabular}{|c|c|c|c|}
\hline LABINCLOG & UNIMPLOG & WAGELOG & @TREND(79) \\
\hline 1.000000 & 0.108975 & -0.276922 & -0.054612 \\
\hline & $(0.04327)$ & $(0.29249)$ & $(0.00942)$ \\
\hline
\end{tabular}

The coefficients displayed in Table 7 are the parameters to estimate the long run elasticities. According to Table 7, coefficient of the UNM rate shows that it has negative association with the LP; hence, every increase in the UNM rate reflects to the LP index by $-11 \%$ in the long run. However, for the LW, it has positive association with the LP. That is the reflection of every increase in the LW is $28 \%$ on the LP.

\subsection{The VECM}

Co-integration theory asserts that the disequilibrium between the variables in the short run may have a tendency to adjust into the long run equilibrium. Co-integration models determine the long run associations of the variables while they do not have in the short run. Therefore, the VECM (refer to the Equation below) was employed to estimate the adjustment coefficient:

$$
\Delta \ln l A P R O D_{t}=\propto_{0}+\sum_{i=1}^{n} \propto_{1 i} \Delta \ln W A G E_{t-i}+\sum_{i=1}^{n} \propto_{2 i} \Delta \ln U N I M P_{t-1}+\gamma E C M_{t-1}+\varepsilon_{t},
$$

$\gamma \quad=$ Error correction term and the speed of adjustment of $\mathrm{ECM}_{t-1}$;

$\Delta \ln L A P R O D_{t-1}=$ Change in the LP index for the $t-1$ period;

$\Delta \ln U N I M P_{t-1}=$ Change in the CP index for the $t-1$ period;

$\Delta \ln W A G E_{t-i} \quad=$ Change in the LW index for the $t-i$ period;

$\mathrm{ECM}_{\mathrm{t}-1}=$ Error terms of the co-integration model in the period $t-1$;

$\mu_{1 i}, \mu_{2 i}$ and $\mu_{3 i}=$ Coefficients or the short-term parameters affecting the dependent variables. 
Table 8. The VECM results

\begin{tabular}{|l|c|c|c|c|}
\hline \multicolumn{5}{|c|}{ Dependent Variable: $\Delta$ ln LAPROD $t$} \\
\hline \multicolumn{1}{|c|}{ Independent Variable } & Coefficient & Std. Error & t-Stat. & Prob. \\
\hline ECM $_{t-1}$ & -0.600010 & 0.149451 & -4.014767 & 0.0005 \\
\hline$\Delta \ln _{\text {LAPROD }}{ }_{t-1}$ & 0.180769 & 0.147034 & 1.229443 & 0.2304 \\
\hline$\Delta \operatorname{lnUNIMP}_{t-1}$ & -0.022444 & 0.106554 & -0.210633 & 0.8349 \\
\hline$\Delta \operatorname{lnWAGE}_{t-1}$ & 1.805353 & 0.451033 & 4.002702 & 0.0005 \\
\hline$\varepsilon_{t}$ & -0.030822 & 0.022017 & -1.399937 & 0.1738 \\
\hline \hline $\mathrm{R}^{2}$ & 0.704366 & Mean dependent var. & 0.052865 \\
\hline Adjusted R & 0.657065 & S.D. dependent var. & 0.072863 \\
\hline S.E. of regression & 0.042669 & A & -3.319685 \\
\hline Sum squared resid. & 0.045516 & SC & -3.086152 \\
\hline Log likelihood & 54.79528 & HQ & -3.244976 \\
\hline F-stat. & 14.89101 & Durbin-Watson stat & 2.187170 \\
\hline Prob(F-stat.) & 0.000002 & \multicolumn{3}{l}{} \\
\hline
\end{tabular}

VECM model (refer to Table 7) verifies the long run associations of the variables by estimating the error term which must be in between -1 and 0 . The ECMt- $1(\gamma)$ coefficient is negative in sign and statistically significant at $0.05 \%$ significance level. Thus, there is a long run causality running from the LW to the LP indexes. The deviations between the variables in the short run gradually diminish and the model closes to the equilibrium in the long run. The speed of adjustment from the short run disequilibrium to the long run equilibrium is shown below:

$$
1 / \gamma=1 / 0.60=1.67
$$

This calculation indicates that the co-integration equilibrium is reached in 1.67 periods.

\subsection{Short term association between the LW and the productivity indexes}

Short run associations of the variables could be checked by utilizing the Wald Test (WT), as presented by Table 9. Thus, the coefficients of the variables in the VECM were tested via WT (refer to Table 8 for the results).

Table 9. Wald Test

\begin{tabular}{|c|c|c|c|c|}
\hline H0 & Statistic & Value & $\mathrm{df}$ & Prob. \\
\hline \multirow{2}{*}{$\alpha_{1}=0$} & F-stat. & 1.511530 & $(1,25)$ & 0.2304 \\
\cline { 2 - 5 } & $\chi^{2}$ & 1.511530 & 1 & 0.2189 \\
\hline \multirow{2}{*}{$\alpha_{2}=0$} & F-stat. & 0.778267 & $(2,19)$ & 0.0703 \\
\cline { 2 - 5 } & $\chi^{2}$ & 1.556535 & 2 & 0.0467 \\
\hline \multirow{2}{*}{$\alpha_{3}=0$} & F-stat. & 16.02162 & $(1,25)$ & 0.0005 \\
\cline { 2 - 5 } & $\chi^{2}$ & 16.02162 & 1 & 0.0001 \\
\hline
\end{tabular}


$\alpha_{1}$ is the coefficient of $\Delta \operatorname{lnLAPROD}{ }_{t-1}$. Probability of the $\chi^{2}$ for $\mathrm{H} 0\left[\alpha_{1}=0\right]$ is $21.9 \%$, which is more than $5 \%$. Thus, the lagged value of the LP has not short-term effect on its current values.

$\alpha_{2}$ is the coefficient of $\Delta \operatorname{lnUNIMP}_{t-1}$ and the probability of the $\chi^{2}$ for H0 $\left[\alpha_{2}=0\right]$ is $4.7 \%$, which is less than $5 \%$. Thus, the short run associations of UNM rate and LP index are not rejected.

$\alpha_{3}$ is the coefficient of $\Delta \operatorname{lnWAGE}_{t-1}$ and the probability of the $\chi^{2}$ for $\mathrm{H} 0\left[\alpha_{3}=0\right]$ is $0.01 \%$, which is less than $5 \%$. Thus, the LW has statistically significant short-term association LP.

\subsection{Model Stability Tests}

Reliability of the model depends on how stabile it is. Unstable models have the residuals suffering from the problems such as heteroscedasticity, serial correlation and abnormally distribution.

Initial condition of the model stability is that the residuals must be normally distributed.

Jarque-Bera statistic and its corresponding probability verify the H0 that the residual of the model is normally distributed. Second condition for the model stability is homoscedasticy of the variables which means they have the same finite variance. According to Heteroscedasticity Breusch-Pagan-Godfrey (HBPG) test results in Table 10, the model is homoscedastic. $\chi^{2}$ value supports the $\mathrm{H} 0$ that the model is homoscedastic at $72 \%$ significance level.

Third condition for the efficiency of the model is that the model's residuals must not be serially correlated. Breusch-Godfrey Serial Correlation (BGSC) LM test results (refer to Table 10 and Table 11) show that the residuals of the model are not serially correlated.

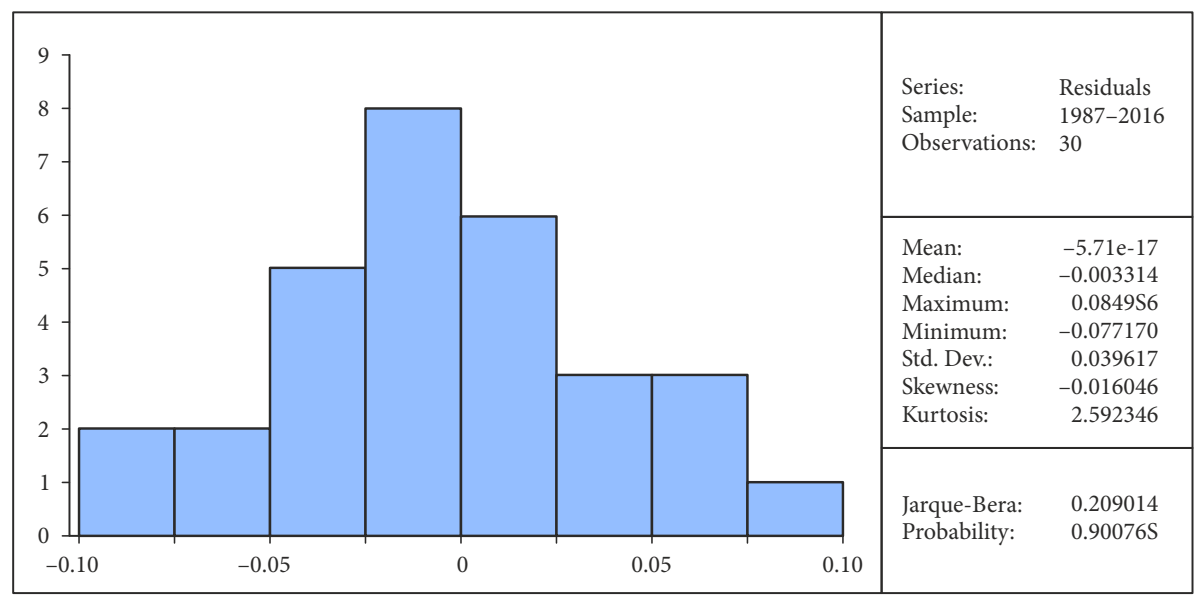

Figure 1. Histogram Normality Test

Table 10. The HBPG test results

\begin{tabular}{|l|c|c|c|}
\hline F-stat. & 1.092032 & Prob. $\mathrm{F}(9,17)$ & 0.3966 \\
\hline Obs $^{\star} \mathrm{R}^{2}$ & 6.651478 & Prob. $\chi^{2}(9)$ & 0.3543 \\
\hline Scaled explained SS & 3.677589 & Prob. $\chi^{2}(9)$ & 0.7202 \\
\hline
\end{tabular}


Table 11. The BGSC LM test results

\begin{tabular}{|l|c|c|c|}
\hline F-stat. & 0.557380 & Prob. $\mathrm{F}(2,16)$ & 0.5803 \\
\hline Obs $^{\star} \mathrm{R}^{2}$ & 1.386819 & Prob. $\chi^{2}(2)$ & 0.4999 \\
\hline
\end{tabular}

\section{Conclusions}

This study analyzes the relationships between the LW, LP index and UNM rate. The JC test shows that the variables are co-integrated. According to the adjustment coefficient estimated by VECM, the speed of adjustment is 1.67 periods from the short run disequilibrium to the long run equilibrium between the variables. Normalized co-integrating coefficient indicates that the LW positively affects the LP index, while the effect of UNM rate on it is negative. These results show that the more wage the labor earns is the more productive $\mathrm{s} /$ he becomes.

Moreover, the Wald Test results on the short run associations of the variables showed that the effect of lagged value of the LP on its current value is not statistically significant. However, the effect of LW is positive and the effect of UNM rate is negative on the LP.

The increase in the wages stimulates the belief of the workforce that they are substantially paid for their work. Their trust and loyalty to the employers also increases. Reflection of this situation on the LP is likely to be positive.

Besides, the increases in UNM rates may adversely affect the LP. Employees may also lose the productivity due to fear of losing their jobs. In addition to this, the increase in UNM rates will increase the number of those wishing to work with lower wages and negatively affect the wages. In this case the employers may have a tendency to employ more unskilled workers because the low wage is a factor that reduces anxiety to be productive.

While the investigation results are consistent with studies reported on the subject and the theoretical causality between wages and productivity, there are also implications for managers. Further wage adjustments are recommended to gain more productivity. The results can also be implemented in assessing wage-setting regarding the implications for employment outcomes. Based on the relationship between the assessed parameters, it is further recommended that the companies experiencing a growth in labour wages to improve their productivity performances, as they may have to (in the long run) reduce their employments to survive.

\section{Acknowledgements}

The authors would like to express their sincere gratitude to the Ministry of Education Malaysia, Universiti Teknologi Malaysia (UTM) and the Research Management Centre (RMC) for providing the financial support for this paper to be published. This study is financed by Razak Faculty of Technology and Informatics and the Trans-Disciplinary Research (TDR) Grant under Cost Centre No Q.K130000.3556.07G00.

\section{Author contributions}

Mustafa Ozturk and Osman Nuri Aras together carried out the data analysis, Serdar Durdyev and Syuhaida Ismail designed and wrote the introduction and literature review of the 
paper. Nerija Banaitienė and Syuhaida Ismail provided extensive advice throughout the study, particularly for the statement of the research problem, methodological approach as well as concluding remarks of the manuscript. The discussion was a team task. All authors have read and approved the final manuscript.

\section{Conflicts of interest}

The authors declare no conflict of interest.

\section{References}

Akerlof, G. A. (1982). Labor contracts as partial gift exchange. The Quarterly Journal of Economics, 97(4), 543-569. https://doi.org/10.2307/1885099

Banaitienè, N., Banaitis, A., \& Laučys, M. (2015). Foreign direct investment and growth: analysis of the construction sector in the Baltic States. Journal of Civil Engineering and Management, 21(6), 813-826. https://doi.org/10.3846/13923730.2015.1046478

Dickey, D., \& Fuller, W. (1981). Likelihood ratio statistics for autoregressive time series with a unit root. Econometrica, 49(4), 1057-1072. https://doi.org/10.2307/1912517

Durdyev, S. (2011). Pareto analysis of on-site productivity constraints and improvement techniques in New Zealand building industry (Master Thesis). Massey University. https://mro.massey.ac.nz/handle/10179/2882

Durdyev, S., \& Ismail, S. (2016). On-site construction productivity in Malaysian infrastructure projects. Structural Survey, 34(4/5), 446-462. https://doi.org/10.1108/SS-12-2015-0058

Durdyev, S., Ismail, S., \& Kandymov, N. (2018). Structural equation model of the factors affecting construction labor productivity. Journal of Construction Engineering and Management, 144(4), 1-11. https://doi.org/10.1061/(ASCE)CO.1943-7862.0001452

Durdyev, S., \& Mbachu, J. (2011). On-site labour productivity of New Zealand construction industry: Key constraints and improvement measures. Construction Economics and Building, 11(3), 18-33. https://doi.org/10.5130/AJCEB.v11i3.2120

Durdyev, S., \& Mbachu, J. (2018). Key constraints to labour productivity in residential building projects: Evidence from Cambodia. International Journal of Construction Management, 18(5), 385-393. https://doi.org/10.1080/15623599.2017.1326301

Ehrenberg R. G. \& Smith, R. S. (2009). Modern labor economics: Theory and public policy (10 ${ }^{\text {th }}$ ed.). Pearson.

Falk, A., Fehr, E., \& Zehnder, C. (2005). The behavioural effects of minimum wages (IZA Discussion Paper 1625). IZA, Bonn.

Forth, J., \& O'Mahony, M. (2003). The impact of the national minimum wage on labour productivity and unit labour costs. London: National Institute of Economic and Social Research. www.lowpay.gov. uk/lowpay/research/pdf/forth.pdf

Granger, C. W. (1969). Investigating causal relations by econometric models and cross-spectral methods. Econometrica, 37(3), 424-438. https://doi.org/10.2307/1912791

Granger, C. W. (1988). Some recent development in a concept of causality. Journal of Econometrics, 39(1-2), 199-211. https://doi.org/10.1016/0304-4076(88)90045-0

Han, S., Ko, Y.-H., Hong, T., Koo, C., \& Lee, S. (2017). Framework for the validation of simulationbased productivity analysis: Focused on curtain wall construction process. Journal of Civil Engineering and Management, 23(2), 163-172. https://doi.org/10.3846/13923730.2014.992468

Karaalp-Orhan, H. S. (2017). Labour productivity, real wages and unemployment: An application of bounds test approach for Turkey. Journal of Economic and Social Development, 4(2), 11-22. 
Katovich, E. S., \& Maia, A. G. (2018). The relation between labor productivity and wages in Brazil. Nova Economia, 28(1), 7-38. https://doi.org/10.1590/0103-6351/3943

Ma, L., Liu, C., \& Reed, R. (2017). The impacts of residential construction and property prices on residential construction outputs: An inter-market equilibrium approach. International Journal of Strategic Property Management, 21(3), 296-306. https://doi.org/10.3846/1648715X.2016.1255675

MacKinnon, J. G., Hang, A. A., \& Michelis, L. (1999). Numerical distribution of likelihood ratio test for cointegration. Journal of Applied Econometrics, 14(5), 563-577. https://doi.org/10.1002/(SICI)10991255(199909/10)14:5\%3C563::AID-JAE530\%3E3.0.CO;2-R

Meager, N., \& Speckesser, S. (2011). Wages, productivity and employment: A review of theory and international data. European Employment Observatory Thematic expert ad-hoc paper. Institute for Employment Studies. http://ec.europa.eu/social/BlobServlet?docId=12058\&langId=en

Meidner, R., \& Rehn, G. (1952). Wages policy under full employment ( $1^{\text {st }}$ ed.). William Hodge, London.

Nazarko, J., \& Chodakowska, E. (2017). Labour efficiency in construction industry in Europe based on frontier methods: Data envelopment analysis and stochastic frontier analysis. Journal of Civil Engineering and Management, 23(6), 787-795. https://doi.org/10.3846/13923730.2017.1321577

Oyeranti, O. A. (2000, June). Concept and measurement of productivity in productivity and capacity building in Nigeria. Paper presented at Proceedings of the Ninth Annual Conference of the Zonal Research Units of the Central Bank of Nigeria. Abeokuta, Nigeria.

Ozturk, M., Durdyev, S., Aras, O. N., \& Banaitis, A. (2019). Productivity as a determinant of labour wage in New Zealand's construction sector. Technological and Economic Development of Economy, 25(5), 900-914. https://doi.org/10.3846/tede.2019.10297

Park, H.-S., Thomas, S. R., \& Tucker, R. L. (2005). Benchmarking of construction productivity. Journal of Construction Engineering and Management, 131(7), 772-778. https://doi.org/10.1061/(ASCE)0733-9364(2005)131:7(772)

Policardo, L., Punzo, L. F., \& Carrera, E. J. S. (2019). On the wage-productivity causal relationship. Empirical Economics, 57(1), 329-343. https://doi.org/10.1007/s00181-018-1428-5

Rao, B. B. (2007). Cointegration for the applied economist. Palgrave Macmillan, UK.

Rezai, A., \& Semmler, W. (2007). Productivity and unemployment in the short and long run. Schwartz Center for Economic Policy Analysis. Policy Note. http://www.economicpolicyresearch.org/images/ docs/research/employment/Semmler-Rezai.pdf

Rizov, M., Croucher, R., \& Lange, T. (2016). The UK national minimum wage's impact on productivity. British Journal of Management, 27(4), 819-835. https://doi.org/10.1111/1467-8551.12171

Sharpe, A., Arsenault, J-F., \& Harrison, P. (2008). Why have real wages lagged labour productivity growth in Canada? International Productivity Monitor, 17, 16-27.

Shoar, S., \& Banaitis, A. (2019). Application of fuzzy fault tree analysis to identify factors influencing construction labor productivity: A high-rise building case study. Journal of Construction Engineering and Management, 25(1), 41-52. https://doi.org/10.3846/jcem.2019.7785

Storm, S., \& Naastepad, C. W. M. (2012). Wage-led or profit-led supply: Wages, productivity and investment. International Labour Office. Conditions of Work and Employment Series No. 36. https://www.ilo.org/wcmsp5/groups/public/---ed_protect/---protrav/---travail/documents/publication/wcms_187309.pdf

Van Biesebroeck, J. (2007). Robustness of productivity estimates. Journal of Industrial Economics, 55(3), 529-569. https://doi.org/10.1111/j.1467-6451.2007.00322.x

Wakeford, J. J. (2004). The productivity-wage relationship in South Africa: An empirical investigation. Development Southern Africa, 21(1), 109-132. https://doi.org/10.1080/0376835042000181444

Yildirim, Z. (2015). Relationships among labour productivity, real wages and inflation in Turkey. Economic Research-Ekonomska Istraživanja, 28(1), 85-103.

https://doi.org/10.1080/1331677X.2015.1022401 